\section{(6) OPEN ACCESS}

\title{
Vitamin D treatment in calcium-deficiency rickets: a randomised controlled trial
}

\author{
Tom D Thacher, ${ }^{1}$ Philip R Fischer, ${ }^{2}$ John M Pettifor ${ }^{3}$
}

\begin{abstract}
${ }^{1}$ Department of Family Medicine, Mayo Clinic, Rochester, Minnesota, USA ${ }^{2}$ Department of Pediatric and Adolescent Medicine, Mayo Clinic, Rochester, Minnesota, USA

${ }^{3}$ MRC/Wits Developmental Pathways for Health Research Unit, Department of Paediatrics, University of the Witwatersrand, Johannesburg, South Africa
\end{abstract}

\section{Correspondence to}

Dr Tom D Thacher, Department of Family Medicine, Mayo Clinic, 200 First Street SW, Rochester, MN 55905, USA; thacher.thomas@mayo.edu

Received 20 September 2013 Revised 21 March 2014 Accepted 24 March 2014 Published Online First 19 April 2014

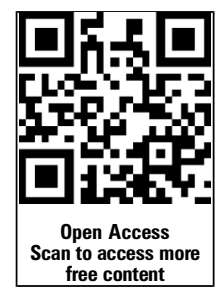

\begin{tabular}{l}
\hline To cite: Thacher TD, \\
Fischer PR, Pettifor JM. Arch \\
Dis Child 2014;99: \\
807-811. \\
\hline
\end{tabular}

\begin{abstract}
Objective To determine whether children with calciumdeficiency rickets have a better response to treatment with vitamin $\mathrm{D}$ and calcium than with calcium alone. Design Randomised controlled trial.

Setting Jos University Teaching Hospital, Jos, Nigeria.

Population Nigerian children with active rickets treated with calcium carbonate as limestone (approximately 938 mg elemental calcium twice daily) were, in addition, randomised to receive either oral vitamin $D_{2} 50000 \mathrm{IU}$ $(\mathrm{C} a+\mathrm{D}, \mathrm{n}=44)$ or placebo $(\mathrm{Ca}, \mathrm{n}=28)$ monthly for 24 weeks.
\end{abstract}

Main outcome measure Achievement of a 10-point radiographic severity score $\leq 1.5$ and serum alkaline phosphatase $\leq 350 \mathrm{U} / \mathrm{L}$.

Results The median (range) age of enrolled children was 46 (15-102) months, and baseline characteristics were similar in the two groups. Mean $( \pm S D)$ 25-hydroxyvitamin D (25(OH)D) was $30.2 \pm 13.2 \mathrm{nmol} / \mathrm{L}$ at baseline, and 29 (43\%) had values $<30 \mathrm{nmol} / \mathrm{L}$. Baseline alkaline phosphatase and radiographic scores were unrelated to vitamin D status. Of the 68 children (94\% of original cohort) who completed 24 weeks of treatment, $29(67 \%)$ in the Ca+D group and $11(44 \%)$ in the Ca group achieved the primary outcome $(p=0.06)$. Baseline $25(\mathrm{OH}) \mathrm{D}$ did not alter treatment group effects ( $p=0.99$ for interaction). At the end of 24 weeks, $25(\mathrm{OH}) \mathrm{D}$ values were $55.4 \pm 17.0 \mathrm{nmol} / \mathrm{L}$ and $37.9 \pm 20.0 \mathrm{nmol} / \mathrm{L}$ in the $\mathrm{Ca}+\mathrm{D}$ and $\mathrm{Ca}$ groups, respectively, $(p<0.001)$. In the $C a+D$ and $C a$ groups, the final $25(\mathrm{OH}) \mathrm{D}$ concentration was greater in those who achieved the primary outcome $(56.4 \pm 17.2 \mathrm{nmol} / \mathrm{L})$ than in those who did not $(37.7 \pm 18.5 \mathrm{nmol} / \mathrm{L}, \mathrm{p}<0.001)$.

Conclusions In children with calcium-deficiency rickets, there is a trend for vitamin $D$ to improve the response to treatment with calcium carbonate as limestone, independent of baseline 25(OH)D concentrations.

Trial registration number ClinicalTrials.gov NCT00949832.

\section{INTRODUCTION}

Nutritional rickets in most Nigerian children results from inadequate dietary calcium intake, rather than vitamin D deficiency. ${ }^{1}$ However, vitamin D requirements and its metabolism in children with dietary calcium-deficiency rickets have not been adequately explored. Children with calcium-deficiency rickets have elevated serum 1,25-dihydroxyvitamin D $\left(1,25(\mathrm{OH})_{2} \mathrm{D}\right)$ values, which nearly doubles in response to a single oral dose of vitamin $\mathrm{D} .^{2}{ }^{3}$ This increase in $1,25(\mathrm{OH})_{2} \mathrm{D}$ in children with calciumdeficiency rickets is suggestive of increased vitamin $\mathrm{D}$ requirements and a relative vitamin $\mathrm{D}$ deficiency, despite 25-hydroxyvitamin D $(25(\mathrm{OH}) \mathrm{D})$ values

\section{What is known about this topic?}

- Nutritional rickets in most Nigerian children results from inadequate dietary calcium intake and responds to calcium supplementation.

- Children with inadequate calcium intake may have greater vitamin D requirements.

\section{What this study adds?}

- Vitamin D in addition to treatment with calcium carbonate as limestone facilitates more rapid healing of rickets in children with calcium-deficiency rickets.

- The response to treatment with vitamin $D$ and calcium was independent of baseline 25(OH)D concentrations.

- A greater increase in serum 25(OH)D concentration over the course of treatment was predictive of successful healing of rickets.

being greater than those generally considered indicative of deficiency. ${ }^{4}$

In a randomised controlled trial, we found that treatment with vitamin D alone was less effective in healing rickets than treatment with calcium or calcium in combination with vitamin D. ${ }^{1}$ The primary outcome of the trial was the combined endpoint of radiographic healing and normalisation of serum alkaline phosphatase, and this outcome did not differ between the groups that received calcium with or without vitamin D. When compared with treatment with calcium alone, the combination of calcium and vitamin $\mathrm{D}$ resulted in a more rapid initial decline in alkaline phosphatase and improvement in radiographic score. Although vitamin D status, as measured by serum $25(\mathrm{OH}) \mathrm{D}$, improved during treatment with calcium alone, the rise in $25(\mathrm{OH}) \mathrm{D}$ and the decline in $1,25(\mathrm{OH})_{2} \mathrm{D}$ were greater when calcium was combined with vitamin $\mathrm{D}$ than with calcium alone.

The objective of this randomised controlled trial was to compare the response of rickets to calcium treatment as limestone with and without vitamin D supplementation.

\section{METHODS}

\section{Subjects}

Children with active rickets were identified using radiographs of the wrists and the knees from 
among children who presented with leg deformities to the primary care setting of the Family Medicine Department of the Jos University Teaching Hospital in the geographic centre of Nigeria $\left(10^{\circ}\right.$ north latitude). Children were eligible for enrolment if they had a radiographic score of at least 2.5 on a validated 10-point scoring method that assessed the severity of rickets in the growth plates of the distal radius and ulna and around the knee. ${ }^{5}$ Approval for the study was obtained from the Ethical Committee of the Jos University Teaching Hospital and the Institutional Review Board of Mayo Clinic, and written informed consent was obtained from a parent of each enrolled child.

Data were collected regarding symptoms of rickets, the frequency and quantity of dairy product intake, and usual sunlight exposure. The percentage of unclothed skin at enrolment was estimated with a Lund and Browder age-related burn chart. Standing height was measured with a wall-mounted stadiometer. Two 24-h dietary recalls were obtained on separate days to determine energy, phosphorus and calcium intake. Energy and mineral intakes were calculated using food composition tables for African foods. ${ }^{6-8}$ Weight was measured with a hanging weighing scale. Anthropometric z-scores were calculated with Epi Info 3.2.2 (CDC, Atlanta, Georgia, USA). All children were examined for clinical signs of rickets.

Dual energy X-ray absorptiometry of the left distal and proximal $1 / 3$ forearm was performed by a single investigator (TDT) with a portable densitometer (Norland pDEXA, Model 476A110). The densitometer had a short-term in vivo precision of $6.4 \%$ for areal bone density at the distal radius and ulna, and $7.2 \%$ at the proximal $1 / 3$ radius and ulna, and a long-term in vitro precision of $1.1 \%$.

\section{Intervention}

All children were treated with calcium carbonate as powdered limestone. Powdered limestone was locally available at a much lower cost than calcium tablets. The content of elemental calcium in $1.0 \mathrm{~g}$ of limestone was $268 \mathrm{mg}$ (courtesy of Michael Gruzak, USDA/ARS Children's Nutrition Research Center, Houston, Texas, USA). Samples of limestone had no toxic concentrations of heavy metals. One level teaspoon of powdered limestone (approximately $3.5 \mathrm{~g}=938 \mathrm{mg}$ of elemental calcium) was mixed with the child's food or porridge twice daily. Enrolled children were randomised by coin toss (performed by TDT) to receive under direct observation either oral vitamin $\mathrm{D}_{2}$ as $50000 \mathrm{IU}$ (ergocalciferol; Pliva, Inc., East Hanover, New Jersey) once every 4 weeks $(\mathrm{Ca}+\mathrm{D}$ group) or placebo, which was a single vitamin B complex tablet, once every 4 weeks (Ca group) for 24 weeks.

Subjects returned every 4 weeks for their supplements and assessment of adverse events. The weight of limestone remaining at each visit was recorded to assess adherence. Height, weight, venous blood, wrist and knee radiographs, and forearm bone density measurements were obtained at baseline and at 12 and 24 weeks after enrolment. Serum samples were stored at $-20^{\circ} \mathrm{C}$ until transported frozen to the Mayo Clinic for analysis. Serum calcium, phosphorus, alkaline phosphatase and albumin were measured with standard methods. Serum $25(\mathrm{OH}) \mathrm{D}$ was measured by isotope-dilution liquid chromatography-tandem mass spectrometry (LC-MS/MS). ${ }^{9}$ Unless otherwise indicated by subscript notation for individual metabolites, 25(OH)D refers to the total concentrations of $25(\mathrm{OH}) \mathrm{D}_{2}$ and $25(\mathrm{OH}) \mathrm{D}_{3}$. Concentrations of $25(\mathrm{OH}) \mathrm{D}$ below the limit of detection $\left(5 \mathrm{nmol} / \mathrm{L}\right.$ for $25(\mathrm{OH}) \mathrm{D}_{3}$ and $10 \mathrm{nmol} / \mathrm{L}$ for $\left.25(\mathrm{OH}) \mathrm{D}_{2}\right)$ were designated as zero for the data analysis.

\section{Statistical analysis}

The primary outcome was the combined attainment of a radiographic score of 1.5 or less and a serum alkaline phosphatase concentration of $350 \mathrm{U} / \mathrm{L}$ or less. All radiographs were scored independently by two of the authors (TDT and PRF) and the mean score was used for analysis. Based on the primary outcome measures of radiographic score and serum alkaline phosphatase values and SDs based on previous studies (1.6 for radiographic score and $150 \mathrm{U} / \mathrm{L}$ in alkaline phosphatase), 40 subjects in each treatment group would provide $80 \%$ power and 95\% CI to detect a difference between groups of 1.0 in final radiographic score and $100 \mathrm{U} / \mathrm{L}$ in alkaline phosphatase.

Data analysis was performed with Excel 2003 (Microsoft Corp., Redmond, Washington, USA) and JMP V.9.0.1 (SAS Institute Inc., Cary, North Carolina, USA). Unless otherwise noted, means and SDs are reported for continuous variables with normal distributions, and medians are reported for nonnormally distributed variables. A paired t-test was used to compare values of continuous normally distributed variables with baseline values, and an unpaired t-test was used to compare values of continuous variables between groups. The Wilcoxon test was used to compare non-normally distributed variables. Logistic regression was used to assess the effect of treatment group on the primary outcome while controlling for baseline group differences and to test for interactions between variables. $\mathrm{p}$ Values less than 0.05 were considered significant.

\section{RESULTS}

A total of 254 children presented with leg deformities, and 72 subjects with radiographically active rickets were enrolled between February 2004 and November 2006 (figure 1). The baseline characteristics at enrolment are shown in table 1 . Because of the nature of coin toss randomisation, the number of subjects in the $\mathrm{Ca}+\mathrm{D}$ group $(\mathrm{n}=44)$ was greater than the number in the $\mathrm{Ca}$ group $(\mathrm{n}=28)$. Unlike classical vitamin D-deficiency rickets, all children were over the age of 1 year at presentation and most had regular sun exposure. Dietary calcium intake was uniformly low, reflecting minimal dairy product intake. Their calcium intakes were well below the Institute of Medicine's estimated average daily requirements of $500 \mathrm{mg}$ and $800 \mathrm{mg}$ for children 1-3 years of age and 4-8 years of age, respectively. ${ }^{4}$ Children's heights were significantly stunted, in part reflecting their leg deformities, but their relatively normal weight for height and serum albumin did not indicate acute malnutrition.

The baseline mean $( \pm \mathrm{SD}) 25(\mathrm{OH}) \mathrm{D}$ concentration was 30.2 $\pm 13.2 \mathrm{nmol} / \mathrm{L}$, and $29(40 \%)$ had values below $30 \mathrm{nmol} / \mathrm{L}$. Baseline alkaline phosphatase and radiographic scores were unrelated to $25(\mathrm{OH}) \mathrm{D}$ concentrations. Baseline dairy product intake was not significantly associated with height for age $(r=0.19)$, weight for height $(r=0.02)$, serum calcium $(r=0.07)$ or $25(\mathrm{OH}) \mathrm{D}$ concentrations $(\mathrm{r}=-0.05)$. However, total dietary calcium intake was positively related to weight for height $(\mathrm{r}=0.29 ; \mathrm{p}=0.01), 25(\mathrm{OH}) \mathrm{D}$ concentration $(\mathrm{r}=0.24 ; \mathrm{p}=0.04)$ and total energy intake $(\mathrm{r}=0.59 ; \mathrm{p}<0.001)$.

Of those enrolled, 68 (94\%) completed 24 weeks of treatment. The median adherence to calcium supplementation, based on the weight of unused limestone, was $99 \%$ in the Ca group and $96 \%$ in the $\mathrm{Ca}+\mathrm{D}$ group $(\mathrm{p}=0.54)$. Alkaline phosphatase values and radiographic scores improved in both groups (figures 2 and 3). In an analysis of alkaline phosphatase values, adjusted for baseline values, mean values were marginally lower in the $\mathrm{Ca}+\mathrm{D}$ group than the $\mathrm{Ca}$ group at 12 weeks $(\mathrm{p}=0.06)$ but not 
Figure 1 Study flow diagram.

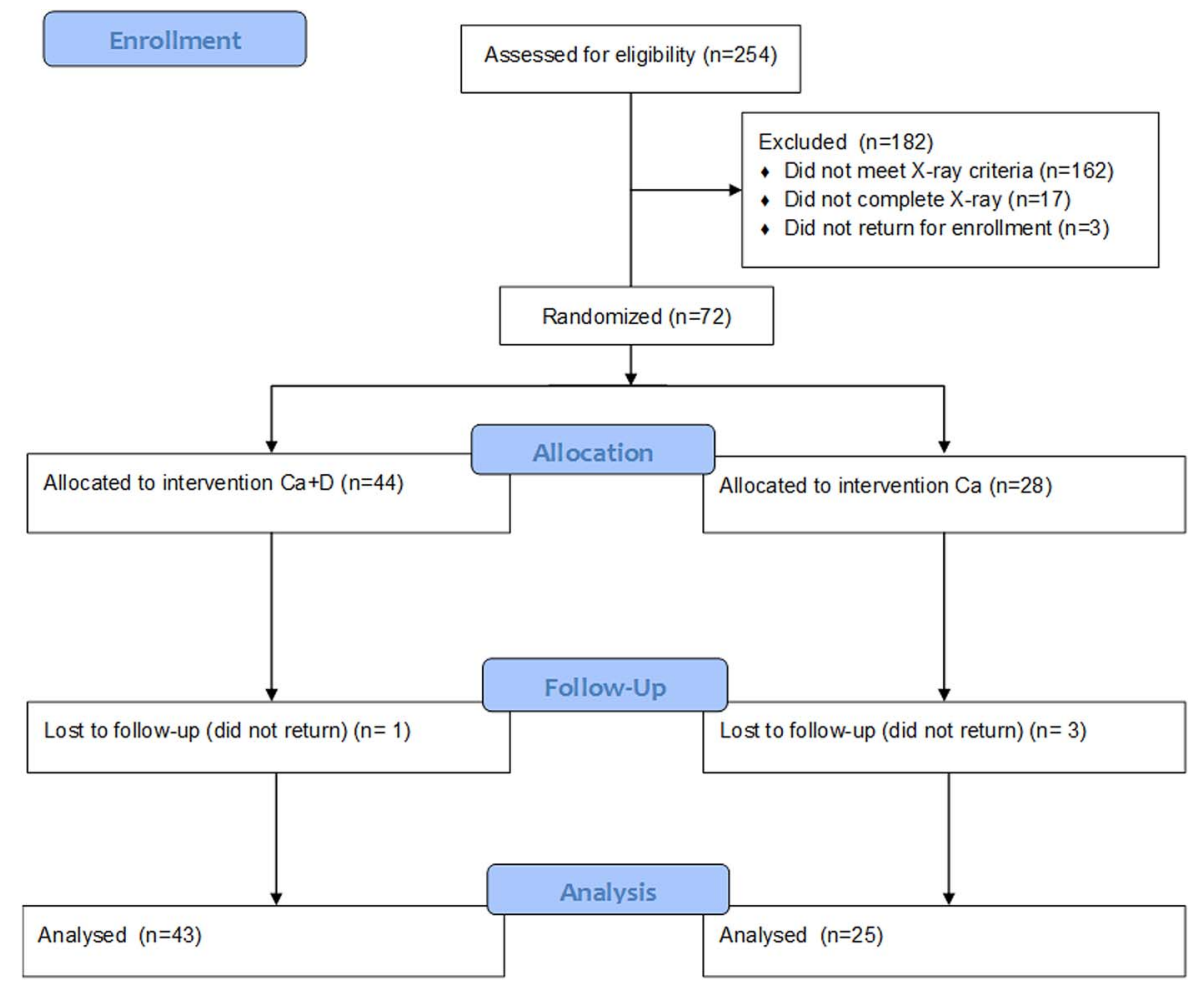

at 24 weeks $(p=0.40)$. Similarly, adjusted mean radiographic scores were lower in the $\mathrm{Ca}+\mathrm{D}$ group at 12 weeks $(\mathrm{p}=0.01)$ but not at 24 weeks $(\mathrm{p}=0.12)$.

At the end of 24 weeks, 29 (67\%; 95\% CI 53\% to 80\%) in the $\mathrm{Ca}+\mathrm{D}$ group and 11 (44\%; $95 \%$ CI $27 \%$ to $63 \%$ ) in the Ca group achieved the primary combined outcome of radiographic and alkaline phosphatase endpoints, and this difference was marginally significant $(\mathrm{p}=0.06)$. At the intermediate time point of 12 weeks, $11(26 \%)$ in the $\mathrm{Ca}+\mathrm{D}$ group and $1(4.2 \%)$ in the Ca group had achieved the combined outcome $(p=0.03)$.

In a logistic regression analysis that controlled for baseline values of alkaline phosphatase, radiographic score, serum 25 $(\mathrm{OH}) \mathrm{D}$ and height for age, treatment with calcium plus vitamin D was significantly superior to treatment with calcium alone (table 2). Interestingly, baseline $25(\mathrm{OH}) \mathrm{D}$ concentration was not predictive of a response to vitamin $\mathrm{D}$, as there was no interaction of treatment group with baseline $25(\mathrm{OH}) \mathrm{D}(\mathrm{p}=0.42$ for interaction).

At the end of 24 weeks, mean serum calcium values increased similarly in the two treatment groups, and mean $25(\mathrm{OH}) \mathrm{D}$ values had increased to $55.4 \pm 17.0 \mathrm{nmol} / \mathrm{L}$ and 37.9 $\pm 20.0 \mathrm{nmol} / \mathrm{L}$ in the $\mathrm{Ca}+\mathrm{D}$ and the $\mathrm{Ca}$ groups, respectively, $(\mathrm{p}<0.001$; figure 4). In the $\mathrm{Ca}+\mathrm{D}$ and $\mathrm{Ca}$ groups, the response to treatment was associated with an increase in $25(\mathrm{OH}) \mathrm{D}$ concentration. Of the 10 subjects with $25(\mathrm{OH}) \mathrm{D}<30 \mathrm{nmol} / \mathrm{L}$ at 24 weeks, two (20\%) attained the primary outcome compared with $66 \%$ of those with $25(\mathrm{OH}) \mathrm{D} \geq 30 \mathrm{nmol} / \mathrm{L}(\mathrm{p}=0.006)$. The final $25(\mathrm{OH}) \mathrm{D}$ concentration was greater in those who achieved the primary outcome than in those who did not (56.4 $\pm 17.2 \mathrm{nmol} / \mathrm{L}$ vs $37.7 \pm 18.5 \mathrm{nmol} / \mathrm{L}$, respectively, $\mathrm{p}<0.001$ ). The increase in height over the course of treatment was significantly related to the final $25(\mathrm{OH}) \mathrm{D}$ concentration $(\mathrm{r}=0.28$; $\mathrm{p}=0.02$ ).

The incremental increase in the distal forearm bone mineral content in the Ca group (least squares mean increase $0.093 \mathrm{~g}$ ) was nearly twice that of the $\mathrm{Ca}+\mathrm{D}$ group (least squares mean increase $0.053 \mathrm{~g} ; \mathrm{p}=0.02$ ) in a model adjusting for baseline bone mineral content and height. However, the increase in proximal $1 / 3$ forearm bone mineral in the $\mathrm{Ca}$ group (least squares mean increase $0.130 \mathrm{~g}$ ) was similar to that of the $\mathrm{Ca}+\mathrm{D}$ group (least squares mean increase $0.109 \mathrm{~g} ; \mathrm{p}=0.22$ ). The increase in distal and proximal $1 / 3$ bone mineral content was unrelated to treatment response, as assessed by the combined outcome of radiographic and alkaline phosphatase endpoints.

\section{DISCUSSION}

We found that vitamin D facilitates more rapid healing, improves vitamin D status and had a marginally significant effect on recovery at the end of 6 months in children with calcium-deficiency rickets treated with calcium carbonate as limestone. The response to treatment with vitamin $\mathrm{D}$ and calcium was independent of baseline $25(\mathrm{OH}) \mathrm{D}$ concentrations. However, a response to treatment with either calcium or calcium in combination with vitamin $\mathrm{D}$ was associated with a greater increase in $25(\mathrm{OH}) \mathrm{D}$ concentrations over the period of therapy than in those who did not respond as well.

In a previous study in this population, we found no difference in the primary outcome between groups that received calcium with or without vitamin $\mathrm{D}$, but there was a more rapid initial decline in alkaline phosphatase in the group that received the combination of vitamin $\mathrm{D}$ and calcium. ${ }^{1}$ In comparing the results of the two studies, we noted that $61 \%$ of the calcium group in the earlier study achieved the primary outcome compared with only $44 \%$ in the current study. Baseline characteristics of children with rickets were similar, and we used the same combined endpoint in both studies. However, several differences between the interventions in the two studies may account for the disparate results. In the previous study, children were treated with calcium as calcium carbonate tablets and vitamin $\mathrm{D}_{3}$ as 600000 IU injections every 3 months, whereas in the present study, we used limestone with a greater dose of elemental calcium and vitamin $\mathrm{D}_{2} 50000$ IU given orally every 
Table 1 Baseline characteristics of groups at randomisation*

\begin{tabular}{|c|c|c|}
\hline Characteristic & $C a+D$ group $(n=44)$ & Ca group $(n=28)$ \\
\hline Age (months) & $55(15-144)$ & $42(16-91)$ \\
\hline Female Sex (\%) & $25(57 \%)$ & $17(61 \%)$ \\
\hline Duration of symptoms (months) & $21.5(0.8-108)$ & $19.1(0.5-61)$ \\
\hline Radiographic score & $5.5(2.6-9.5)$ & $5.9(2.8-10)$ \\
\hline Exposure to sunlight (h/day) & $2(0-8)$ & $1(0-8)$ \\
\hline Exposed skin (\%) & $31(19-47)$ & $37(19-47) \dagger$ \\
\hline $\begin{array}{l}\text { Dairy product calcium intake } \\
\text { (mg/day) }\end{array}$ & $11(0-321)$ & $36(0-200)$ \\
\hline Dietary calcium intake (mg/day) & $174(75-402)$ & $168(70-589)$ \\
\hline Dietary energy intake (kcal/day) & 1116 (477-1954) & $1046(627-2318)$ \\
\hline Height for age z-score & $-3.78(-7.37$ to -0.30$)$ & $-3.02(-5.97$ to 0.27$)$ \\
\hline Weight for height z-score & -0.04 ( -2.58 to 1.91$)$ & $-0.57(-2.15$ to 1.45$)$ \\
\hline \multicolumn{3}{|l|}{ Serum biochemistry } \\
\hline Calcium (mmol/L)‡ & $2.1(1.6-4.0)$ & $2.1(1.3-3.0)$ \\
\hline Corrected calcium (mmol/L)§ & $2.0(1.5-2.8)$ & $2.0(1.2-2.5)$ \\
\hline Phosphorus (mmol/L)ף & $1.1(0.4-2.3)$ & $1.2(0.7-1.8)$ \\
\hline Alkaline phosphatase (U/L) & 599 (291-2670) & $522(268-2183)$ \\
\hline Albumin (g/L) & $44(30-78)$ & $45(38-64)$ \\
\hline $25(\mathrm{OH}) \mathrm{D}(\mathrm{nmol} / \mathrm{L})^{* *}$ & $29.5(0-50)$ & $31.7(10-70)$ \\
\hline $25(\mathrm{OH}) \mathrm{D}<30 \mathrm{nmol} / \mathrm{L}$ & $18(41 \%)$ & $11(39 \%)$ \\
\hline \multicolumn{3}{|l|}{ Bone densitometry } \\
\hline \multicolumn{3}{|l|}{ Distal radius and ulna } \\
\hline Areal bone density $\left(\mathrm{g} / \mathrm{cm}^{2}\right)$ & $0.127(0.081-0.237)$ & $0.129(0.057-0.189)$ \\
\hline Bone mineral content $(\mathrm{g})$ & $0.245(0.162-0.699)$ & $0.249(0.072-0.567)$ \\
\hline Bone area $\left(\mathrm{cm}^{2}\right)$ & $2.084(1.494-2.996)$ & $2.096(1.257-3.307)$ \\
\hline \multicolumn{3}{|l|}{ Proximal $1 / 3$ radius and ulna } \\
\hline Areal bone density $\left(\mathrm{g} / \mathrm{cm}^{2}\right)$ & $0.183(0.130-0.304)$ & $0.194(0.139-0.326)$ \\
\hline Bone mineral content $(\mathrm{g})$ & $0.333(0.239-0.656)$ & $0.342(0.214-0.722)$ \\
\hline Bone area $\left(\mathrm{cm}^{2}\right)$ & $1.878(1.495-2.467)$ & $1.836(1412-2.312)$ \\
\hline \multicolumn{3}{|c|}{ 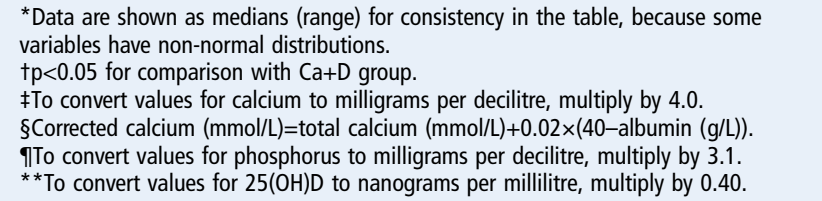 } \\
\hline
\end{tabular}

4 weeks. Calcium as limestone may be less bioavailable than calcium in tablets of calcium carbonate. Because the limestone was mixed with food or porridge, children who did not finish their food would not have had a complete dose. This may explain, in part, the difference in outcomes between the calcium groups in the two trials. The primary outcome in the $\mathrm{Ca}+\mathrm{D}$ group was achieved in $67 \%$ of subjects in this study compared with $58 \%$ in our prior study. Compared with our earlier study, the superior outcome of the $\mathrm{Ca}+\mathrm{D}$ group in this study may reflect an effect of dosing of vitamin D every 4 weeks as opposed to a larger dose administered every 12 weeks. Effective healing of rickets in the $\mathrm{Ca}+\mathrm{D}$ group indicates that the bioavailability of calcium from limestone was sufficient when vitamin D status was optimised. Limestone can be used as an inexpensive source of calcium in low-income countries where rickets is prevalent.

In comparison, a recent trial in 67 children with nutritional rickets in India compared treatment with calcium, vitamin D or the combination for 12 weeks. ${ }^{10}$ Normal serum alkaline phosphatase and complete radiological healing were observed in $12 \%, 16 \%$ and $50 \%$ of subjects in the calcium, vitamin D and combination groups, respectively. The Indian children were younger (median age 14 months) than children in our trial, but baseline $25(\mathrm{OH}) \mathrm{D}$ values (median $34 \mathrm{nmol} / \mathrm{L}$ ) were similar. The

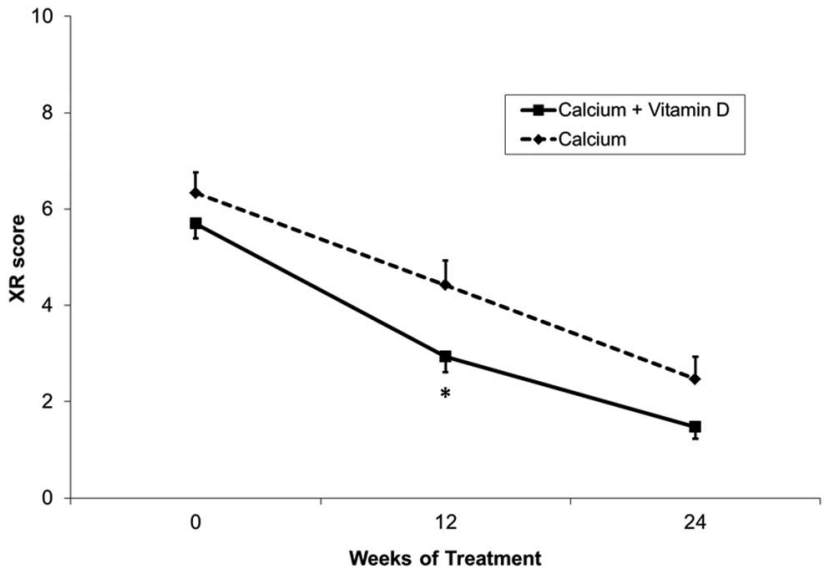

Figure 2 Radiographic score response. Error bars represent SE of the mean. Asterisk indicates $p<0.05$ for difference between groups, adjusting for baseline score.

authors concluded that treatment of children with nutritional rickets and low dietary calcium intakes responded better to the combination of vitamin $\mathrm{D}$ and calcium than to calcium alone. Their trial did not examine healing of rickets beyond 12 weeks, the relationship of $25(\mathrm{OH}) \mathrm{D}$ with treatment response or the effect of treatment on bone density.

It is not clear why vitamin D enhances healing of rickets in children with calcium-deficiency rickets, even in those with adequate vitamin D status, as we have previously shown excellent intestinal calcium absorption without $\mathrm{D}$ supplementation. Vitamin D does not improve the already maximal fractional calcium absorption in Nigerian children with rickets, even in those with low serum $25(\mathrm{OH}) \mathrm{D}$ concentrations. ${ }^{11}$ Studies in adults indicate that intestinal calcium absorption is not significantly reduced until $25(\mathrm{OH}) \mathrm{D}$ concentrations are $\leq 10 \mathrm{nmol} /$ L. ${ }^{12}$ Current evidence indicates that vitamin $\mathrm{D}$ requirements are greater when dietary calcium intakes are low. ${ }^{3}{ }^{13}$ This is consistent with our findings in Nigerian children with calciumdeficiency rickets, who demonstrate a marked increase in 1,25 $(\mathrm{OH})_{2} \mathrm{D}$ in response to vitamin $\mathrm{D}$ administration. ${ }^{2}{ }^{3}$ These findings suggest that vitamin $\mathrm{D}$ metabolites may have a direct or indirect effect on bone mineralisation by mechanisms other than calcium absorption. ${ }^{14}$ Vitamin $\mathrm{D}$ also promotes intestinal

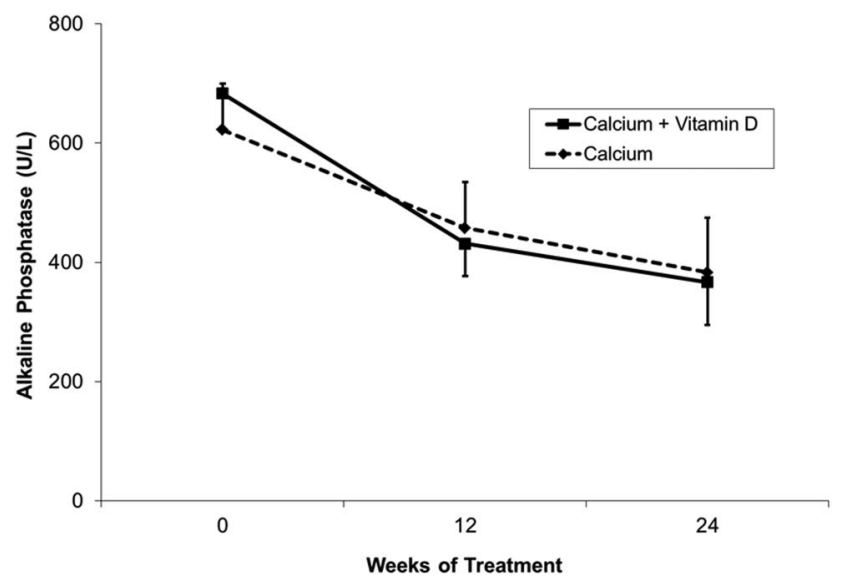

Figure 3 Serum alkaline phosphatase response. Error bars represent SE of the mean. No significant differences were present between groups. 
Table 2 Logistic regression analysis of factors at enrolment predictive of primary outcome

\begin{tabular}{lcc}
\hline Baseline term & OR $(95 \% \mathrm{Cl})$ & p Value \\
\hline Alkaline phosphatase (U/L) & $0.998(0.994$ to 1.000$)$ & 0.03 \\
Radiographic score & $0.73(0.50$ to 1.0$)$ & 0.06 \\
25(OH)D (nmol/L) & $0.95(0.90$ to 1.0$)$ & 0.06 \\
Height for age z-score & $1.8(1.1$ to 3.2$)$ & 0.01 \\
Treatment (Ca+D/Ca) & $5.4(1.3$ to 27$)$ & 0.02 \\
\hline 25(OH)D, 25-hydroxyvitamin D. & &
\end{tabular}

phosphorus absorption and mediates phosphorus metabolism, which may also be critical for healing of the rickets.

Surprisingly, the increase in bone density of the distal radius and ulna was greater in the $\mathrm{Ca}$ group than in the $\mathrm{Ca}+\mathrm{D}$ group. Nutritional rickets impairs endochondral ossification at the growth plates, and the growth plates of the radius and ulna are located distally near the wrist. We have previously demonstrated that calcium supplementation increases forearm bone density in young Nigerian children, ${ }^{15}$ but this increase was not sustained after withdrawal of calcium supplementation. ${ }^{16}$

One of the limitations of our study was that we did not attain our target enrolment of 40 subjects in each group before the study concluded. The power of our sample size to detect the observed difference in the primary outcome (67\% vs $44 \%)$ with $95 \%$ CI was $46 \%$. However, this lack of power does not affect the conclusions related to our findings that were statistically significant. Coin toss randomisation led to unequal group sizes, but this method of simple randomisation is less error prone than restricted randomisation, because it is entirely unpredictable. However, it is more likely to generate baseline imbalances between the characteristics of the treatment groups, which we did not observe in our trial. Trials that are numerically imbalanced are still scientifically sound, and loss of power occurs only when the imbalance is much greater than $2: 1 .^{17}$

Even children with nutritional rickets resulting from insufficient dietary calcium benefit from vitamin $\mathrm{D}$ supplementation in addition to calcium to promote more rapid healing. Limestone can be used as an inexpensive source of calcium in low-income countries.

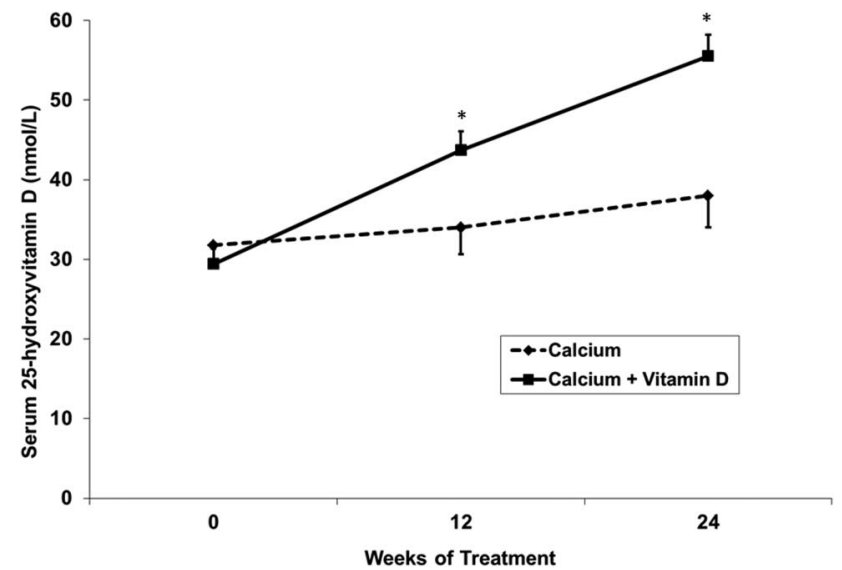

Figure 4 Serum 25(OH)D response. Error bars represent SE of the mean. Asterisks indicate $p<0.05$ for difference between groups, adjusting for baseline concentration.
Contributors TDT, PRF and JMP were responsible for conception and design. TDT acquired the data and performed the data analysis. All authors interpreted the data and critically revised the manuscript for important intellectual content. TDT obtained funding, drafted the manuscript and is the guarantor. TDT affirms that the manuscript is an honest, accurate and transparent account of the study being reported; that no important aspects of the study have been omitted and that any discrepancies from the study as planned and registered have been explained.

Funding This study was supported by Grant Number 1 UL1 RR024150 from the National Center for Research Resources (NCRR), a component of the National Institutes of Health $(\mathrm{NIH})$ and the NIH Roadmap for Medical Research. Its contents are solely the responsibility of the authors and do not necessarily represent the official view of NCRR or NIH. Information on NCRR is available at http://www.ncrr. nih.gov/. Information on Reengineering the Clinical Research Enterprise can be obtained from http://nihroadmap.nih.gov. The study sponsor had no role in study design and the collection, analysis, and interpretation of data and the writing of the article and the decision to submit it for publication.

Competing interests All authors have completed the ICMJE uniform disclosure form at http://www.icmje.org/coi_disclosure.pdf and declare: TDT reports grants from National Center for Research Resources, during the conduct of the study; personal fees from Biomedical Systems, outside the submitted work; no other relationships or activities that could appear to have influenced the submitted work. PRF and JMP have nothing to disclose.

Ethics approval This project was approved by the Mayo Clinic Institutional Review Board and the Jos University Teaching Hospital Ethical Committee.

Provenance and peer review Not commissioned; externally peer reviewed.

Open Access This is an Open Access article distributed in accordance with the Creative Commons Attribution Non Commercial (CC BY-NC 3.0) license, which permits others to distribute, remix, adapt, build upon this work non-commercially, and license their derivative works on different terms, provided the original work is properly cited and the use is non-commercial. See: http://creativecommons.org/ licenses/by-nc/3.0/

\section{REFERENCES}

1 Thacher TD, Fischer PR, Pettifor JM, et al. A comparison of calcium, vitamin D, or both for nutritional rickets in Nigerian children. N Engl J Med 1999;341:563-8.

2 Thacher TD, Fischer PR, Isichei CO, et al. Early response to vitamin D2 in children with calcium deficiency rickets. J Pediatr 2006;149:840-4.

3 Thacher TD, Fischer PR, Obadofin MO, et al. Comparison of metabolism of vitamins $D(2)$ and $D(3)$ in children with nutritional rickets. J Bone Miner Res 2010;25:1988-95.

4 Institute of Medicine. Dietary reference intakes for calcium and vitamin D. Washington, DC: The National Academies Press, 2011.

5 Thacher TD, Fischer PR, Pettifor JM, et al. Radiographic scoring method for the assessment of the severity of nutritional rickets. J Trop Pediatr 2000;46:132-9.

6 Latham MC. Human nutrition in tropical Africa. Rome: Food and Agricultural Organization of the United Nations, 1979.

7 Food composition table for use in Africa. Agricultural Extension and Research Liaison Services. Soyabeans in the Nigerian diet. Extension bulletin no. 21. Home economics series no. 1. Zaria, Nigeria: Ahmadu Bello University, 1985:62-71.

8 Gouws E, Langenhoven ML, eds. NRIND food composition tables. 2nd edn. Parow, South Africa: South African Medical Research Council, 1986.

9 Singh RJ. Quantitation of 25-OH-vitamin D (25OHD) using liquid tandem mass spectrometry (LC-MS-MS). Methods Mol Biol 2010;603:509-17.

10 Aggarwal V, Seth A, Marwaha RK, et al. Management of nutritional rickets in Indian children: a randomized controlled trial. J Trop Pediatr 2013;

59:127-33.

11 Thacher TD, Obadofin MO, O'Brien KO, et al. The effect of vitamin D2 and vitamin D3 on intestinal calcium absorption in Nigerian children with rickets. J Clin Endocrinol Metab 2009;94:3314-21.

12 Need AG, O'Loughlin PD, Morris HA, et al. Vitamin D metabolites and calcium absorption in severe vitamin D deficiency. J Bone Miner Res 2008;23:1859-63.

13 Steingrimsdottir L, Gunnarsson 0, Indridason OS, et al. Relationship between serum parathyroid hormone levels, vitamin D sufficiency, and calcium intake. JAMA 2005;294:2336-41.

14 Anderson PH, Turner AG, Morris HA. Vitamin D actions to regulate calcium and skeletal homeostasis. Clin Biochem 2012;45:880-6.

15 Thacher TD, Fischer PR, Isichei CO, et al. Prevention of nutritional rickets in Nigerian children with dietary calcium supplementation. Bone 2012;50:1074-80.

16 Umaretiya PJ, Thacher TD, Fischer PR, et al. Bone mineral density in Nigerian children after discontinuation of calcium supplementation. Bone 2013;55:64-8.

17 Hewitt CE, Torgerson DJ. Is restricted randomisation necessary? BMJ 2006;332:1506-8. 